\title{
SKOLOMBO AND THEIR CONTINUED EXISTENCE: REVISITING LOST HUMANISM AND PARENTIFICATION IMPULSE
}

\author{
CHINYERE L. OKAM ${ }^{1}$ \\ ${ }^{1}$ University of Calabar, PMB 1115 Calabar, Cross River State-Nigeria, Nigeria. ORCID: 0000-0001-5408- \\ 8608, Email: clookam@gmail.com
}

ABSTRACT: This paper examines the Skolombo-street children of Calabar. It also investigates the reason for their continued existence, the derivatives in form of social and economic insecurity, inequality and other monstrosities visible in their presence. It questions the oblivious role of the institutions responsible for the care of the child, and parentification impulse as well as the lost humanism which existed in high premium in traditional African society resisted and reflected by text and language. The study is anchored upon Theo Van Leeuwen's perspective on Critical Discourse Analysis which primarily studies the way social-power abuse and inequality are enacted, reproduced, legitimized, and resisted by text and talk in the social and political context. The study is a qualitative research conducted with the eclectic research methodologies such as biography, Participant Observation and Conversation. Among other findings, this study reveals that the Cross river state government has not provided enough fair ground to fully tackle the social and economic needs of the street child, that the desired comfort has not been provided for the girl child and that they have not been able to fully integrate the Skolombo into the echelon of the privileged. Conclusively, this has created spaces for youth delinquency, thievery, moral laxity and decadence. In the light of the findings, it is recommended that the government needs to put alternative and effective measures to play with the aim to curbing the menace of Skolombo and the street child culture. There ought to be an implementation of the child right 
act in the global space in order to reduce the molestation and marginalization of the boy and girl child. Stringent punishment should be meted on parents, religious leaders and guardians who subject children to unnecessary molestation. Religious leaders and parents should be sensitized about the need to integrate their children within the family, intervention should be made compulsory.

KEYWORDS: parentification, integrative humanism, language, CDA, binaries of power, capability deprivation

\section{INTRODUCTION}

\section{Street children in Nigeria: From general to the Scolombo and Lacasera girls}

Nigeria has her fair share of the street children phenomenon. This tradition holds sway in almost all her regions. Children whose lives are abused from home as a result of religious and cultural belief and due to poverty (Okam 2019:2) are commonly found in the country. In Southern Nigeria, one witnesses innumerable group of children and adults (who started as children) infiltrate the streets of cities, roaming the corners of villages and taking solace in inhuman places unworthy for a child born by parents that belong to a community. Some of these people are tagged Agberos, Boys Oye, Skolombo, and so on as the names vary in different geographical spaces in the south. In the same vein, in Northern Nigeria, there abounds the Almajiri culture, where children who ought to be in their parents' homes but due to religious practices are displaced at tender ages of five years and above to live with their religious instructors. In his seminal research on the Almajiri tradition, Zakir, Abubakar, Lawal, Imrana, Habibu, Hassan, \& Harande (2014:129) affirms that "in almost every street, corner, junction - especially in the north are young, homeless, poor, neglected and maltreated children seen roaming the streets begging for food and alms. These children are called the Almajiris (a student who leaves his parents for quranic education...when such Almajiris return to their villages, they participate in the act of selling and taking drugs". Zakir states further that "the Mallams/Alaramma (both female and male instructors) do not allow their children to mingle with the Almajiris to the extent that they allow their own children to attend formal school (Zakir et al. 2014:129). This fully captures the exclusion of the street child from the society in Northern Nigeria-what Jurgen Herbamas, Gayatri Spivak, Homi Bhabha, Ranajit Guha, El Habib Louia and Antonio Gramsci in their studies on power, ideology and subaltern postcolonial discourse articulate as the degradation and dehumanization of the other. The other, are those categories of people who have been dwarfed by those in the center of discourse. They are women, the black race, LGBT, and minor ethnic nationalities that have been placed at the margin for ages. Children in this category could also be situated within this context since they are also prone to the dehumanisation of the other. This dehumanisation on the other hand, constructs the view of the life to approaching socio-cultural issues. This manifestation is fully captured in social vices and moral decadence perpetuated by these children. The Skolombo experience in Cross River State, Nigeria is not an exception. 
In fact, PIND report (2017:1) makes us understand that:

The Cross River State capital has been faced with rising insecurity as a result of violence and criminality attributed to street children locally called "Skolombo Boys" and "Lacasera Girls." These homeless children beg for alms and scavenge for recyclable materials on the street and have become a problem to residents of the state. From roaming the street for survival in bands, some have formed into criminal gangs. They have been associated with incidents of robbery, kidnapping, rape, pick-pocketing, and drug abuse.

The adverse effect of the street child on the socio-economy therefore cannot be overemphasized. The absence of care distorts and obscures the future of the child who grows to become a menace to the society. This is what Amartya Sen (1999:14) terms "capability deprivation". The major challenges the Skolombo child faces are lack of money, inadequate parental care and ideological excesses that prepare them toward a future of inhumanity, hate and dispassion and above all to see nothing worth existing for when death could mean a better beginning for them.

This brings us to the concept of inclusion and exclusion, as drivers of the continued existence of the Skolombo. By inclusion we mean the bond of unity that exists between individuals and their social environment. This is created by a condition where people find a space in the society. In their study on the inclusion and exclusion dichotomy, Gidley. J. M, Hampson, G.P., Wheeler, L., \& Bereded-Samuel, E. (2010:47) aver that

from the perspective of social justice ideologies, increasing social inclusion is about human rights, egalitarianism of opportunity, human dignity, and fairness for all. It may or may not be linked to economic interests, but its primary aim is to enable all human beings to participate fully in society with respect for their human dignity.

This requires the creation of a good atmosphere with infrastructure and specific activities together that enables one to respond meaningfully to his felt needs and those of his immediate community and avoid the derivative of being a threat to the society. We examine the opposite of social inclusion as social exclusion. This stems from the fact that the terms are relatively categorical binaries that either suggests a person's vulnerability or capability. The quote below fully articulates a contradiction.

We live in the state and in society; we belong to a social circle which jostles against its members and is jostled by them; we feel the social pressure from all sides and we react against with all our might; we experience a restraint to our free activities and we struggle to remove it; we require the services of other [people] which we cannot do without; we pursue our own interests and struggle for the interests of other social groups, which are also our interests (Allman 2018:1).

Allman went further to expound that

social exclusion describes acts of social stratification across human and animal societies, as a principle to reflect the ordering that occurs within societies to determine social position, and as a narrative to explain and at times justify why 
one or more groups merit access to the core or the periphery, to the benefit or expense of others (Allman 2012: 7).

The "elements of exclusion like deprivation and inequality as phenomena that occur at the very margins of society, and by extension, are to ignore social structures that influence the included as well as the excluded" (Bowring quoted by Allman 2012: 9). It is against the background of inclusionism that we deduce the appropriateness of what social exclusion portends. Thus, our discussion of the term inclusion and exclusion investigates the society and how the deprived have found a way to be included in the systems that ostracizes them.

However, we must understand that precursory to the colonial experience, traditional African societies were characterized by proper establishment of families.

Family functions were patterned by pathways, governed by mores and reinforced by moral codes for proper child socialization and upbringing... community opinion and spirit governed the behavior of parents in terms of child rearing practices and so parents tended to conform to the standard so as to avoid the sanctions from the community (Geertz 1975: 144).

However, colonial and neocolonial processes coupled with capitalist and religious culture(s) displaced the ever favourable Nigerian cum African norms and ethos. Against this backdrop, the questions that emanate from these studies are, how have religion and the family affected the exclusionist and inclusionist culture characteristic of the street child in Nigeria-especially as it relates to the Skolombo practice in Cross rivers state? And what measures can be used to humanise and parentisise the Skolombo child in Cross River State? What measures can be used to involve every stakeholder in the resocialisation, and humanisation of the Skolombo? Furthermore, this study examines how these children understand their situation in the street and how they identify themselves in the homeless experience. It investigates how they can access social assistance.

The street child lives in slums and ghettos in the cities. Paradigms of the rigours of the life experienced by them - the Skolombo inclusive are well captured in popular culture-film, on television drama, theatrical performances, poetry, music among others. The street child malaise forms the crux of films such as Totsi, Jonny Mad Dog, New Jerusalem, among others. Their homelessness makes them take solace in having abodes in uncompleted buildings, markets, motor parks among other odd places. While walking on the streets is the norm for them, they also engage in some kind of economic activity including scavenging in dustbins, carrying loads for people in the marketplaces and all sorts of menial jobs. They also live on the street (of the street) and children from street families (abandoned) these ones live outside the normal family environment and maintain occasional ties with their families and fending for themselves outside the family homes (UNICEF 2007: 2).

According to PIND (2017: 3) report, "in recent times Calabar, the Cross River State capital has been faced with the problem of Skolombo. The skolombo (scolombo) is a name for street children in Calabar the capital city of Cross River State-Nigeria. But what led to the emergence of the Skolombo? A lot of issues led to their emergence. Ak- 
pan (2015:1) affirms that "the major cause or origin of Scolombo could be traced to the family and the church". The accusations of witchcraft by mostly Pentecostal churches and traditional religion practitioners are some of the prime causes of Skolombo practice. Lack of parental care, high poverty rate, maltreatment and abandonment of children when a parent dies have also been major reasons for this Miasma. This makes these children to go to the street and mix up with miscreants who introduce them to the hard way of survival. They have also been linked with incidents of kidnapping, rape, cult clashes, and political violence among other vices. Some children are also of single parenthood. Paradigmatically, in cases where their mothers are unable to fend for them, such children tend towards taking to the street. In a conversation with a social worker, Mr John Ekpe, (Akpan 2015: 1) states that:

Some parents are running up and down looking for what to eat. Some leave children with housemaids. How they dress or grow up do not matter again to parents. In those days, parents check, but now we harbour anything in our home. These help to spoil our home. All of us are responsible for these problems, including the church. You go there, they will call a child a witch. There is no job and poverty has taken over. There is poverty in the midst of plenty, but there is money in the hands of a few. Some people even sell their children to make money. There is a total breakdown in the family system.

According to PIND Report (2017: 1), “in 2015, the Cross River State government inaugurated a special security task force code-named Operation Skolombo to address the menace of street children in the state capital. This initiative, however, has not been able to effectively address the problem as violence and criminality associated with street children is still prevalent, particularly in Calabar". With the failure of the government in curbing this menace, the question that emanates in the next section of the paper is, what measures can be used to humanize the Skolombo child in Cross River State?

\section{METHODOLOGY OF RESEARCH AND THEORETICAL FRAMEWORK}

The study adopts an eclectic research method- a conglomeration of diverse methodologies of research (Kumar: 2013: 1). This includes such methodologies as observation, conversational and biographic tools. Furthermore, in order to analyze the emerging issues and answer the key questions arising from this research, the frame of parentification and humanism provides an understanding of the monstrous derivatives of the Skolombo as each concept places a strong emphasis on the causal elements of their condition. The research also proffers ways in which normalcy through platforms that enable liberal and conservative discourses using soft power and other conversational methodologies can be restored.

To create basis for the argument in this study, it is necessary to situate it within a methodological stance/s that could complement the foregoing. Thus, the adoption of eclectic approach is pertinent. Ozumba (2010:41) describes eclecticism as the "systematic joining of ideas or facts for the purposes of meaningful picturing of reality. It 
involves borrowing, networking, sifting and gluing ideas or facts together. Eclecticism is derisive of other methods thus not foreclosing free participation and articulation. The import of this method is because of the complexities of the population of study regarding their orientation and context of study. If a strict formal research method is applied, getting the Skolombo to participate will end in energy dissipation. Thus, the justification of combining these tools. The methodological plurality we will be looking at are: Observation, Biographical and Conversational methodologies. On this premise, it is pertinent to examine the views of scholars on the observation orientated form of research. Participant observation serves as an instrument for this research. This enables the researcher to generate themes systematically by being involved in the context of the research as well as observing the behaviors of the population of study.

At the level of biographical methodology, it is the basic way to get to know the social reality through the study "of the personal relationships through which the individual expresses his experiences and communicates ways of understanding the social reality (Gorzko 2004:1). The subject of research in the biographical approach is life of a particular person presented by him or her in a narrative form (Bednarz-Łukaszewska 2012 quoted by Babara Chojnacka 2008). This helps the subject in learning the reality in which he functions and which he co-creates (Trzebiński 2002 quated Babara Chojnacka 2018). By telling about events from his life, the individual can reflect upon his experiences and interpret them. The biographical narrative interview helps the researcher with gathering information about the individual perception of the world, the closest surroundings, and experiences by the participant of the research. The subject presents his past - the course of his life from his own point of view.

Furthermore, the study also involves conversation with the street children. "Conversation suggests a connection that is sustained" (Feldman 1999:1). Amongst the characteristics of conversation is an 'exchange of views... that consists of connected remarks. Another characteristic of conversation is cooperation and a will to participate. Buchmann (2002:4) notes that "people do not insist that partners follow, it is enough that they enter into conversation". The validity of conversation in research cannot be overemphasized. Personnel engaged in with interview in the study are in the Skolombo of Lemna Camp Calabar. They are this researcher, three members of the Non-Governmental Organization offering the Skolombo help through preaching of the word of God, feeding, and general welfare within their capability. In addition, a student of the university where the researcher works also comes to the fore in the conversation process.

The study is anchored upon Theo Van Leeuwen's perspective on Critical Discourse Analysis. CDA "primarily studies the way social-power abuse and inequality are enacted, reproduced, legitimated, and resisted by text and talk in the social and political context" (Van Dijk 2015:466). Critical Discourse Analysis abbreviated CDA, "provides the reader with valuable and pertinent results” (Allagbe and Amoussu 2018:11). Fairclough and Woodak (1997:259) in Critical Discourse Analysis summarize Van Leeuwen's main tenets of CDA viz:

$1 \mathrm{CDA}$ addresses social problems

2 Power relations are discursive 
3 Discourse constitutes society and culture

4 Discourse does ideological work

5 Discourse is historical

6 The link between text and society is mediated

7 Discourse analysis is interpretative and explanatory

8 Discourse is a form of social action

The eight tenets provided by Fairclough and Woodak are used to interrogate the place of power and dominance in the examination of the Skolombo street child in Cross River State. Furthermore, integrative humanism serves as the theoretical base for our emotional and mental discourse.

\section{REFLECTIONS ON POSITIONING: CAPABILITY DEPRIVATION, LOST HUMAN- ISM AND PARENTIFICATION}

Parentification is a salient attribute of the street child phenomenon. The term parentification refers to "the process through which children are assigned the role of an adult, taking on both emotional and functional responsibilities that typically are performed by the parent. The parent, in turn, takes the dependent position of the child in the parent-child relationship" (Engelhardt 2012: 45). In this context, there is a distortion of positions where the child is not only independent, he also plays the role of the parent whose biological parents become dependent on them. Parentification is most times disadvantageous. This stems from the fact that it becomes a burden on the child who does not enjoy the benefits of dependency. Due to the dislocation of positions, the child is made to believe that he/she must fend for himself and also for the parents and those around him. He becomes conscious of the obligation(s) the society has placed upon him. Globally, and especially in third world countries, parents who encounter financial difficulty sometimes turn to their children for financial assistance. Mehta (2019: 11) argues that parentification is a "form of child labour". This transcends the physical manhandling of the child. It also encompasses the psychological. Emotional and even spiritual distortion of the humanity of the child.

In Nigeria, some parents promote the street hawking tradition. While they sit in the confine of their homes, they compel the children to take a particular commodity into the street for sale. Paradigmatically, some of the interviewed Skolombo and Lacasera children make us understand that they prostitute, steal and indulge in other vices in order to fend for the aged parents and grandparents. Most parentified children amongst the Skolombo and Lacasera girls are deprived of their capability in the formal sector. They are not given the opportunity to explore the formal education which in turn inhibits and deprive them from bringing their capability to the fore. The parentified child is a child who is dispossessed of humanity. This dehumanisation in turn caused isolation and depression. Isolation and depression set in when the child at such a tender age is unable to cope with the rigours of life created by the society. Parentification therefore could be "instrumental (physical) or emotional" (Mehta 2019:13). While the former involves the child being assigned tangible tasks, in the latter, the child becomes the parent's confidant or intermediary. 
This notwithstanding, any attempt to reintegrate the child back into the fold of humanism would otherwise amount to applying what Ozumba calls "Njikoka" - Integrative humanism - a rational construct that attempts to vouchsafe man's ultimate happiness through proper and authentic earthly existence (Ozumba \& Chimakonam 2014:7). It is about being an "agent of penetrating and pervading harmony in the community of humans whether at the family, village, state, tribe, national international or institutional levels" (Ozumba and Chimakonam 2014: 8). The fundamental of this is teamwork "Ijikota aka onu" or "Ofu Obi" (Ozumba and Chimakonam 2014: 8). This is why Theatre for development method is advocated in this work as a veritable platform to actualize the rehumanisation.

\section{REHUMANIZING THE STREET CHILD: THE CASE OF THE SKOLOMBO}

The United Nations' Child's right act has always advocated for the protection of the child. It has always reiterated that "domestic courts can be a powerful catalyst for enforcing claims of rights holders and promoting accountability on the part of duty bearers. Efforts should be made to promote public interest litigation on behalf of women and children" (Goonesekere and Alwis 2005:47). Appropriate measures must be taken for children such as the Skolombo to be integrated into the society. This is an integrative humanist model where the society must absorb these street children by first teaching them the moral and accepted socio-cultural norms of the society. Then integrating them back into their families as well as creating a capability ground for their survival since one of the reasons of their continued existence is the recourse to economic opportunities.

Humanism believes in an ethics or morality that grounds all human values in this-earthly experiences and relationships and that holds as its highest goal the this-worldly happiness, freedom, and progress-economic, cultural, and ethical-of all humankind, irrespective of nation, race, or religion...in a far-reaching social program that stands for the establishment throughout the world of democracy, peace, and a high standard of living on the foundations of a flourishing economic order, both national and international... with full freedom of expression and civil liberties, throughout all areas of economic, political, and cultural life (Lamont Corliss 1997: 14-15). Ozumba (1997:58) also presupposes that integrative humanism is key to the rational construction which attempts to vouch for man's ultimate happiness through proper and authentic earthly existence.

\section{Conversation with Skolombo: 14 samples}

It is very pertinent to clarify that 30 conversations where held with the skolombo with the help of the members of the Non Governmental Organization taking care of them and a Master's Degree student of the Department of Theatre, Film and Carnival Studies, University of Calabar-Nigeria. Out of the 30 samples 14 were taken as they reflect the concerns of the others not stated here. 
Sample 1. My name is Effiong Edet Effiom. (Male) I am from Ikot Ansa in Calabar municipal. My Aunt told me I was born in the year 2000. I used to stay with my parents. My father is late. My mother abandoned me and travelled to Lagos as I was told. My father has a house he left behind. My uncles said they were going to be paying my fees from the rent of the rooms, but my uncles did not pay. They took my father's properties. That is why my mother's brother took me to Odukpani. My father's friend took care of me, then my maternal uncle later took me to Odukpani. But my uncle's wife didn't take care of me much. She was always accusing me of stealing even when I didn't commit the offense. She was always keeping me hungry. Then a friend of mine named Shola, told me about this camp. Then I was attending Comprehensive Secondary School, Odukpani. I was in Junior Secondary Class 1 . Here in Lemna Camp, we only feed by selling scrapes. We scavenge for plastics, aluminum, bottles, irons, rods, etc. We pack them and heap them until the heap reaches the level of selling. For the metals, it's sold \#30 per kilo. For the disposable empty water bottle containers, it goes for \#15 per kilo. We sell it each week; sometimes we could make up to 5 or 10 thousand naira in a month. But before then, we borrow \#2000 from Obongowan- our master to feed, then, refund after selling. We have four masters here. My own master's name is Island. Each of us belong to them respectively. Also, I give part of my money to a food vendor, so that I can be getting food to eat, and when I don't have money, she will be giving me food on credit.

On Saturdays, these people (pointing to the NGO team) come to feed us and discuss with us to know how we are doing. Some of us give them our money to keep for us. Also, some people come here to give us clothes and shoes. The greatest challenge we have is hunger, because we stay hungry too much, especially when there is nothing to pick. Mosquitoes bite us so much. Our houses at times drip water when the rain falls. Then bigger ones intimidate us too. We don't really have time to sleep because those refuse trucks come mostly in the night, and we have to be awake to struggle for the scraps, if not no food for us and no money too. People also abuse us when we go out to pick scraps too. At times, I fall ill. I would like to go back to school to be able to have a certificate. I don't like this place (He ended the conversation when a friend of his distracted him with a drink).

Sample 2. Esther Edet Udo (female), Ikot Ekpene LGA, Akwa Ibom State. I am ten years old. I stay with my mother; my father is late. He died in Ikot Ekpene, so mummy relocated to Calabar. It's been up to three months since I came here. My siblings are here with me. We used to live at Ikot Enebong, around 8th mile. We had a house there. When my daddy died, my uncles had a dispute with my mummy over our house. It was a big quarrel which resulted in the arrest and imprisonment of my mum. It was not easy for us. So, when mummy returned, she could not afford to rent a house, so we came here to live. My mum is inside the camp working as I am talking to you. I used to go to school. I was in primary four. 
The name of my school was Nassarawa Primary School, Calabar. We select refuse objects and sell to feed. We gather them until it gets to a certain level, then we sell them. At times we sell up to a thousand naira, at times up to three thousand. After selling, we give our money to Obongowan - our leader here to keep for us. My challenge is that I will have to make money to feed my siblings too. This place is too cold, and we do not have enough clothes. Sometimes we stay hungry and we will have to go and beg for money or pick foods from refuse bins in town to feed myself and my younger ones. Mosquitoes bite us so much. I want to go back to school so that I can read and write. If you can, please help me.

Sample 3: My name is Iniobong Akpan John (male). I am from Ibiono local government area, Akwa Ibom State. It's like I'm up to 12 or 15 years (From his look, he is above 18). My father is late, and my mother left us while we were still young. We reside here in Calabar. Our house is quite close. Most times I go home when I finish selling my goods. We are nine in number, and I am the first son. I try to support my siblings that are in school financially and provide food too. I came to this camp in December 2017. We feed by selling objects - plastic disposable water containers, aluminum, irons, rods, etc. I keep them for up to a month before selling them at the price of $\# 12,000$. Within the month, while I wait, I pick disposable bottle water containers to sell as to be able to feed. The measurement for the disposable water plastics is, when we collect it, we fill it in a mosquito net, and that goes for \#1,200 for 20kilos. It's not easy to gather up to that amount to sell. I don't have much challenges because I go home often. Others don't intimidate me because I am also big. Nobody steals here, because we have not heard that anybody's wares have been stolen before. Obongowan does not want anybody to fight because we are like a family here. My major challenge is waiting to sell off my wares because that is when I get money. I had to struggle to get this boot I am wearing when an NGO came to assist us with few, it wasn't easy at all (smiles mischievously). I would like to go to school up to university level. I am coming (He ran away with a shout out to his friend).

Sample 4. My name is Eunice Christopher Edet (aka Mma Ette). I am from Idep Offiong Umoh, Akpabuyo LGA of Cross-river State. I am 14 years old. My father is still alive. He stays at Uwanse Street, Calabar. Nobody pursued me from home; I came to see my brother and since then I have not decided not to go back home. My parents are alive. My mother comes here at times to check on us. Me too, I visit them once in a while. How we feed is that "Obongowan", my master gives me wares to go and sell. Only few clothes that I have. I don't like here, I would like to go back to school (interference in a friendly manner from one of the NGO members), You don't like here and you are still here because of your BF. Mmmh HIV is real oo. (Eunice runs away) You can see how she is flaunting her well-manicured nails. In the night she and others go to sleep with those lorry drivers over there. And when the return, their boyfriends here take some of the money from them and still sleep with them unhindered. 
Sample 5. My name is Ezekiel Anietie Okon (male). I am from Ikono LGA, Akwa Ibom State. I don't know my age. I have been here in this place since 2010. My mother left me in Ikot Ekpene; my father abandoned me in the hands of my (paternal) grandmother. Then my brother died and I'm the only one left. So one day I accompanied a friend to Calabar. It was my first time. I lived on the street before I came here. Since then, I don't even know where my father is. Every morning, we wake up very early to wait for the refuse trucks. We scavenge for scraps we sell to make money. We also look for clothes, shoes, even foods that are not completely spoilt - we eat them. People used to come and give us food always, but not anymore except this people (NGO) who come when they can. It hasn't been easy. As you can see, we are many here. If you go up there (in the camp), you will see we are more than 100 or 200 people. We are all attached to different Masters who look after us. At times, I fall ill, and when we fall ill, we buy medicine from the pharmacy, but like now I'm having cough and catarrh. I'm waiting to sell my wares so I can go and buy medicines. And there is too much mosquitoes and cold, but we are used to this harsh situation now (If I buy medication for you will you take? I won't give you money because... don't you smoke?). I will (He smiled) we (gesticulating smoking) just do a little. (Pointing at the boys that were smoking by the plantain trees). Sometimes we need to do hard things to allow us to do the hard jobs in the camp. I would like to learn a trade. Something like bag making or blending of soup condiments. I'd like to learn any handwork (craft).

Sample 6. My name is Favour Asuquo Edet (female). I am from Idundu village in Akpabuyo LGA, Cross River State. I am 14 years I am an orphan. I grew up with my grandmother. So, while staying there, my big aunty whose children were not living with her (because I didn't meet any) took me to her house to stay with her. I used to attend Bishop King Inyang Primary School, close to Edgerly Street, Calabar South. So, I continued schooling at my Aunt's place. I was not always given food, and I was always driven for fees. So, I started going out and returning late. My aunt got angry and accused me of associating with witches and stopped me from eating her food. I was starving and started taking her money to feed. Then she pursued me from home completely. In this place that I am Obongowan gives us wares to hawk and make returns. We feed from it. My only problem is that I don't have clothes and I don't feed well. I need money. I'd like to go back to school. There is a place at Queen Duke Street I could stay with my friend there and be attending school. That my friend, I once stayed with them after my aunty pursued me from home. While staying there, I used to hawk boiled groundnuts. I once accompanied that my friend to Anambra to (silence) ...when we returned, I decided to come here and stay because I was not getting money. But, now its school that I want (She was given a pat on the back by their NGO friends, in relation to the unsaid. But I needed to know in clear terms what that description is, so from her explanation, I got that prostitution couldn't favor them in Anambra).

Sample 7. My name is Esther Effong Edet, I am fourteen years old, from Oduk- 
pani Local Government area of Cross River State. My parents are dead. I was staying with my uncle who accuses me always of killing my parents. This accusation is like a threat because he usually tells me to sleep with him before he pays my school fees. I refused his sexual advances and left the hose when I discovered the Lemna Dump site. I joined other children to pick scrapes from the refuse bins. I don't like this job, but I rather stay on it than going back to my uncle.

Sample 8. I won't tell you my name. My parents are in Ikang. I just need help. I don't want to stay in the dump anymore (She has been raped many times by bigger boys outside the camp. Even the lorry drivers sometimes sleep with her without giving her money. She is facing a lot of subjugation from the boys here because she doesn't have a permanent big boy friend here).

Sample 9. My name is Gift Michael Okon. I am from Ibekue in Uyo axis of Akwa-Ibom State. I came from a family of three girls and two boys. Our parents are dead. I was living with a man and one day in 2017 my brother came and beat him up because he has not paid my bride price. Out of anger, the man left me, and my child and I was pregnant with the second child. So, I came to the Waste management site through the help of a friend called Promise. My first child is 9 years old. His name is Moses ThankGod Ibiang, the second is David ThankGod Ibiang. He is five months old People usually come here to give us aids. They call us skolombo and that name is derogatory because of what the society ascribe to it. (Looking fiercely into my eyes) I am a hustling woman. The way you teach to earn a living is the way I pick scrapes to earn a living. People who eat Nigeria money are not skolombo but a group of people who come together under one interest to do legal business is skolombo. By the way who gives the boys gun for thuggery. Just leave me alone. I am tired of all this stereotyping and insult. (I embrace her, wiped her tears with my towel and she relaxes. After a while the conversation continues). I am saving my money now to train my children. I can't watch them suffer here.

Sample 10: My name is David Eyo Okon. I am from Ikot Nakanda in Akpabuyo Akpabuyo local Government Area of Cross River. I am 15 years old. My mother returned one day and told me that she was told by the Church (author withheld name) said that I am a witch. I joined some people I know to do this job of picking scrapes. I make \#500 daily with a woman that collects daily contribution from us. When I get that money, I will run to my paternal grandmother's house.

Sample 11: Peace Bassey Okon. 17 years old. I don't know my father. When my mother died, my grandmother always maltreats me after taking alcohol. She did not put me in school. I saw one of my friends called Favor and she brought me here. I was deceived that some people will help us go to school, but that was not the case. I sleep with Tipper drivers and other men and they pay me N1000 every night. When they don't want to pay, they beat me up. I use condom to protect myself, but when I miss my period, I take drugs. I was once raped by three of our boys at Watt Market Complex Centre. They took turns without condom. If I 
shout, they beat me, after raping me, they left with my money. Even these ones here sleep with us any time they are in need, they beg us, and they don't beat us. I have spent five Christmas here. I have tested for HIV and I am not positive. I am afraid and will like to leave here.

Sample 12: My name is Emmanuella Bassey Ason (she withheld where she came from). I am 14 years old. I used to pick scrapes and I stopped. I am not doing anything. (Interference by one of them... "Say what you do"). Leave him, the bigger boys have sex with us forcefully. If you refuse, they choke you. Three of them can sleep with you in a day if you refuse to give them (interference from a regular caregiver... "Ma they sleep with each other. But it shocked them when Alice died of HIV/Aids. But they still do it"). Ma please take my phone and call me anytime you want to take me out of here. (I took the number and dialed to confirm). (Her tears and expression made me to call her afterwards to ask how she didn't stay long with me, but discovered that she was assaulted by a boy that day who forced her into sex when she is feeling sick and hungry, I am still in contact with her).

Sample 13. My name is Emmanuel Samuel David. I am from somewhere in Oron, Udesiegieti in Mbo LGA I am eighteen years old. I collect Scrapes, I do laundry for people too. I live in Afokang by Okon Inyang I make an average of \#1000 daily. Sometimes I don't get a kobo (Nigerian coin) I live in katakpo. I had a girlfriend before but now no. I want to be alone (Interference) (Why will he have a girlfriend when he can sleep with anyone, he likes... eeh!). My dad is a timber dealer with two wives and 12 children. And my mum a petty trader. She has six of us. I stopped school at SSI. The Oga here buys our goods (Scrapes) some of these girls you see leave us here and go to tanker drivers to prostitute. (Grins mischievously) Anyway I use condom on them. (Walks out like a giant oppressor).

Sample 14: My name is Happiness Victor Edet, I am from Ikpe in Ibiono LGA of Akwa-Ibom State. I am 18 years old (Interference. You? Eighteen?) (... no! they are lying because they know you are no more a child when you are above 18. You will find out, says the lady with the NGO), I am pregnant for somebody, but we are not married. His name is Idongesit, he is also from Akaw-Ibom. I don't know if we will marry, I can leave the child for him after birth but on the condition that he settles my elder brother because my parents are dead. I don't like the character he is showing me now, so I can't marry him. I am seven months pregnant, when I struggle, he will eat from it, have sex with me any time he feels to. As I am, I have 4 children, two boys for him and two girls for my late husband. He said he is not the owner of the children so he cannot feed them. My parents are dead, my partner is living in my mum's house. I come here with these children, most times we sleep here, and when it's convenient for us we go home. I don't want to farm. I like picking scrapes with my children, and I make twenty to fifty thousand naira per month. I save greater part of the money so that I will send my children to school. (She protects here children, but the girl wants freedom and the boys are all willing to be the first to give her independence). (Have they given her? I 
asked. She spoke to a male there and he laughs and immediately frown his face).

\section{A DISCOURSE ANALYSIS OF THE SKOLOMBO INCLUSION AND EXCLUSION IMPULSES}

This discourse analysis looks at the language of the skolombo in the presented conversation. Van Leeuwen articulates that the link between text and society is mediated. This mediation is facilitated by language-the medium through which ideas are passed across by an encoder to a decoder. Asouzu (2007: 87) contends that "Language is a cognitive act of the mind". To understand the skolombo perception of their reality, we have to look read their language. This is because, "It is in language that coherence and order that characterize a man's action as something logical are objectified and made evident. It is not restricted to mental discourse but stretched out to all modes of communication as something meaningful both to us and our world" (Asouzu 2007: 86-88).

I implore a sympathetic and experiential understanding to the narratives of the skolombo. This sis because of the challenges in the country resulting in hunger, strain in parental and family relationship (Okam 2019: 38). Thus, producing a reason for the skolombo recourse to destructive inclusion.

Van Leeuwen's perspective on critical discourse analysis posits that power relations are discursive. The discursivity of power articulates that power is in the hands of the privileged.

In the conversation with Effiong Effiom Edet, an occupant of the Lemna Camp, the Skolombo narrates how he is being maltreated and accused falsely by his aunt led to his venturing into the street world. His statement below fully captures the fact that power is in the hands of the priviledged (from Sample 1).

It reflects that the child's lack of power leaves him at the mercy of the powerful in the society. Furthermore, Van Leeuwen notes that Critical Discourse Analysis addresses social problems. In other words, the Skolombo menace is a social construct. These street children are constructed by the society. This researcher's conversation with the some of the street children reveals that their parents are still alive while they - the street children endeavor to fend for themselves. This is an exemplar of parentification- a situation where the child is excluded from a life of humanism and included into a harsh reality that serves a better course for him at the immediate. The parents' inability to cater for the children pushes them into the street to source for means of livelihood. In a conversation with Eunice Christopher Edet, the researcher realizes that the girl's parents are still alive. In so far, the state of poverty in the home, which is a product of the society, forces her into prostitution. She reveals that she is 14 years old and that she sleeps with lorry drivers for financial gratification. In fact, she states that:

Eunice: My father is still alive. He stays at Uwanse Street, Calabar. Nobody pursued me from home; I came to see my brother and since then I have not decided not to go back home. My parents are alive. My mother comes here at times to check on us. Me too, I visit them once in a while. How we feed is that "Obon- 
gowan”, my master gives me wares to go and sell.

Like the parents of some other street children, Eunice's father and mother have no choice than to allow their daughter engage in prostitution and drug abuse. Girls such as her are popularly known as Lacasera girls. This stems from the fact that it does not cost a man more than offering them a bottle of Lacasera or its financial equivalent to sleep with them.

Van Leeuwen's perspective on critical discourse analysis posits that Discourse is a form of social action. While the Skolombo miasma is a social action, the Cross River State government has also taken measures with the aim to curbing this social malaise. One of such measures is the inauguration of a special task force created in 2015 "codenamed 'Operation Skolombo' to address the menace of street children in the state capital. This initiative, however, has not been able to effectively address the problem as violence and criminality associated with street children are still prevalent, particularly in Calabar" (PIND Report 2017:1). This punitive measure is not what is really needed. Socio-economic exclusion is linked with poverty, and deprivation. Here deprivation is seen within the ambit of capability deprivation- lack of capability to live a minimal descent life. It is the function of the community-the government to provide the capability ground that all its citizens should strive on (Sen: 2000:4).

The Skolombo and Lacasera street children in Cross Rivers State are part of the historical process. In traditional African societies, there is the belief in witchcraft. It is the norm for children to be initiated into the witch cult with the food items. Many a time, a witch confesses that she was initiated into the witch cult by an older female neighbor, an aunt, a cousin, stepmother or even a family friend with a meal. This socio-cultural and historical process has led to the exclusion of such children from becoming part of the family, exclusion from family activities as well as parentification. In an interview, a Skolombo, named Favour Asuquo Edet makes us understand that her grandmother who she lives with sends her out of her (The grandmother) home on the ground that she (Favour) eats from outside the house, and must have been given witchcraft to eat. The grandmother's belief in Witchcraft from the traditional setting vis-a-vis her church and the society lead to her depriving Favour from eating her food. The history of havoc wrecked on the family and society by witches leads to Favour's exile from home. David Eyo Ekon, a victim of witchcraft accusation narrates his ordeal thus:

David: My name is David Eyo Okon. I am from Ikot Nakanda in Akpabuyo Akpabuyo local Government Area of Cross River. I am 15 years old. My mother returned one day and told me that she was told by the Church (author withheld name) said that I am a witch. I joined some people I know to do this job of picking scrapes. I make \#500 daily with a woman that collects daily contribution from us. When I get that money, I will run to my paternal grandmother's house.

Children such as Favour who have been degraded socially and psychologically, end up suffering from "low socioeconomic status, low educational achievement, mental illness including depression and substance abuse" (Allman 2013:8-10). The Skolombo female counterpart-the Lacasera girls end up engaging in early sexual behavior, which 
on the other hand could metamorphose into contracting sexually transmitted diseases such as HIV and AIDS. Van Leeuwen's perspective on critical discourse analysis posits that discourse constitutes society and culture. Discourse is gotten from the society and culture. Culture determines the way discourse is approached. The relativity of culture portends that discourse is particular and must be approached as such. Discursive approaches change since societies and cultures are in a constant state of flux. The Skolombo discourse must be interpreted from within the African ambit and context. Africa within which Cross River State is situated detests incestuous relationships. Esther Effiong Edet, a fourteen years old's attempt to fend away her uncle's attempt to start an incestuous relationship with her, leads to her resorting to living in the Lemna Dump site for. Esther is accused of the death of her parents. This fully captures the rigors the child, especially the girl child goes through in the society Expectedly, the societal expectations of each gender predict such patterns of heterosexual behaviors he exudes (Onuekwe and Okam 2017: 37) but this has transcended normalcy to incestuous act. "The history of humanity shows that people seek power and tend to capitalize it and extend power over more and more territory, more subjects if they are able to". The event under discussion is an extension of such inhuman and immoral power (Anna Odrowaz-Coates 22017:17) Statements lends credit to this. In fact, Esther expatiates that she would rather remain in the Lemna camp site than go back to her uncle.

Most of the street boys and girls do not want to be called the name, Skolombo. They see the name as derogatory. Gift Michael Okon, a Skolombo complains about the manner in which people refer to them. Her interpretation of the name suggests her awareness that they are looked down upon in the society. They are being considered the dregs of the society. Their displacement and feeling of unhomeliness make them think they have been ostracized from the society and integration is almost impossible. Despite their almost helpless situation, they take solace ostracizing themselves from the oppressors. This fully reveals the reason some of them refuse to divulge their identity. In an interview with the researcher, a particular Lacasera girl (a female Skolombo) refuses to give her name. The conversation goes thus:

Lacasera Girl: I won’t tell you my name. My parents are in Ikang. I just need help. I don't want to stay in the dump anymore. (She has been raped many times by bigger boys outside the camp. Even the lorry drivers sometimes sleep with her without giving her money. She is facing a lot of subjugation from the boys here because she doesn't have a permanent big boy friend here).

In the bid for survival, the street child becomes a tool in the hands of the society which has facilitated his dehumanisation. In a broader spectrum, it has come to the fore that the populace's abuse of the Lacasera girls holds sways more to that of the Skolombo boys. While their male counterparts indulge in delinquency, petty thievery and other forms of social vices, the Lacasera girls are sexually abused by the Skolombo boys, lorry drivers, and other sex perverts. It is explicit that contracting HIV and AIDS, and carrying out abortion becomes the aftermath of such experiences. 


\section{HARMONISING RESOURCES FOR SKOLOMBO REHUMANISATION: THE CASE OF THEATRE FOR DEVELOPMENT}

The idea of bringing stakeholders on a platform to engage their action would produce success towards humanising the Skolombo. The fact that the construction and reconstruction of a fair society occur when democratic situation, collectives cannot be overlooked in the discourse of cutting barriers of development. Children should be given the chance to air their position, as Smaradan Cioban posits that "liberation and emancipation perspective give greater value to children's ability to choose what is right in their interest, claiming that society should grant them the right to participation (2018:80). Thus, the author suggests a platform that stimulates participation, ownership, learning, negotiation, consensus, empowerment and accountability. I make bold to state that Theatre for Development has the capacity to mitigate the required culture needed for this function.

It is a communication tool accessible to divergent community with simple engaging processes that can access their previous actions in order to inform their innovative techniques and avenues in how to bring specific activities together to respond meaningfully to his needs and that of his immediate community (Okam 2014: 75).

The TFD process includes but is not limited to these processes, familiarizing with issues and stakeholders. Using popular forms of communication which can help people identify problems and reflect on it and devise solutions towards making change in a particular initiative. Mda (1993: 181) acknowledges that through Theatre, people were able to analyse the structure of domination and dependence, to make their own resolution in response to and to decide the best methods of implementing the resolution because the messages come from their own perspective. This leads to Abah et al's (2009: 1) assertion that "TFD is a methodology for understanding complex problems while at once providing a tool for overcoming them".

Thus, this paper suggests that any individual or group should use this platform which progresses from community (of concern: ideological or cultural) participatory research, to analysis, to performance of issues generated before the various relations to the interrogation of the content of the performance. This progressively moves to stating categorically issues that enhance a particular situation and one that counters it. Having gone through these processes, actions are planned and interested stakeholders locate the action point of their preference for implementation. Monitoring and evaluation are required to ensure that actions identified are realised.

This fully captures how TFD encourages accountability to produce required development. As Shortall and Shucksmith (1998:75) posit that "development is about enabling communities to have greater control over their relationship with the environment and other communities". One will no doubt contend the fact that TFD can raise a discourse platform that levels the binaries of power for inclusivity, through the social positioning of all as humans in search of the good of their society whether as a receiver or capability provider. It is imperative to note that the aim of performance 
in TFD is to reach consensus. "A consensus when it is not possible, the process at the very least exposes and clarifies the different views and allows the building of agenda for negotiation" (Guba \&Lincoln 1989: 1).

\section{CONCLUSION}

The Cross-river state government has not provided enough fair ground to fully tackle the social and economic needs of the street child. The desired comfort has not been provided for the girl child. They have not been able to fully integrate the Skolombo into the echelon of the privileged. Molestation and marginalisation of the street child still hold sway in the Nigerian society. This has created spaces for youth delinquency, thievery, moral laxity and decadence. In the light of the above, the government needs to put alternative and effective measures to play with the aim to curbing the menace of Skolombo and the street child culture. There ought to be an implementation of the child right act in the global space in order to reduce the molestation and marginalisation of the boy and girl child. Stridgent punishment should be meted on parents, religious leaders and guardians who subject children to unnecessary molestation. Religious leaders and parents should be sensitised about the need to integrate their children within the family circle. Parenting intervention should be made compulsory.

FUNDING: This research was funded by the UNESCO/Janusz Korczak Chair fellowship 2019 obtained through the Polish Commission for UNESCO

CONFLICT OF INTEREST: The author declares no conflict of interest.

ACKNOWLEDGEMENTS: I would like to thank the members of the NGO that takes care of the Skolombo at Leman site who equaled as research assistance in the conversations and my Master of Arts student, Bencourage Odey who helped me during the conversations.

\section{REFERENCES}

Abah, Steve, Okwori, Jenkeri. 2009. "Participatory theatre and video: Acting against violence in Northern Nigeria.” IDS Bulletin 40 (3): 19-26.

Allagbe, Ayodele and Franck Ammousu. 2018. "Principles, Theories and Approaches to Critical Discourse Analysis.” International Journal on Studies in English Language and Literature 6(1): 11-18. DOI: http://dx.doi.org/10.20431/23473134.0601002).

Allman, Dan. 2013. “The sociology of Social-Inclusion.” SAGE Open 3(1): 1-16. DOI: $1177 / 2158244012471957$.

Akpan, Aniette. 2015. “Skolombo, the Story of Calabar Street Children.” Sunday Magazine-The Guardian Nigerian Newspaper-Nigeria and World News. Retrieved June 11, 2018 (https://guardian_ng/sunday-magazine/skolombo-the story-of-calabar-street-children/).

Amos, Patricia. 2013. "Parenting and Culture - Evidence from Some African Communities.” IntechOpen. http://dx.doi.org/10.5772/56967.

Chojnacka, Barbara. 2018. "Destructive sense of responsibility in individuals with ex- 
perience of parentification: A biographical perspective." Pp 33-39 in Social Pedagogy and Social Education: Bridging Traditions and Innovations Social Pedagogy Association, edited by D. Keller, K. O’Neil, H. Nicolaisen, D. Schugurensky, and K. Villaseñor. Phoenix, Arizona.

Cioban, Smaranda. 2018. "Exploring how Children Perceive their Work, Case Study Salaj County, Romania." Pp. 79-118 in Children and Youth in varied Socio-Cultural Contexts: Theory, Research, Praxis, edited by U. Markowska-Manista. Warsaw: Wydawnictwo Akademii Pedagogiki Specjalnej.

Dijk, Teun. 2015. Critical Discourse Analysis. USA: John Wiley and Sons.

Engelhardt, Jennifer. 2012. "The Developmental Implications of Parentification: Effects on Childhood Attachment." Graduate Student Journal of Psychology 14: 4552.

Fairclough, Norman and Ruth Wodak. 1997. “Critical discourse analysis.” Pp. 258-84 in Discourse as Social Interaction: Discourse Studies: A Multidisciplinary Introduction, edited by T. Dijk. Thousand Oaks, CA: Sage.

Geertz, Clifford. 1975. The Interpretation of Culture. New York: Basic Books Inc.

Gidley, Jennifer, Hampson, Gary, Wheeler, Leone \& Bereded-Samuel, E. 2010. "Social Inclusion: Co text, Theory and Practice.” The Australasian Journal of UniversityCommunity Engagement 5(1):6-36.

Goonesekere, Savitri and Alwis Rangita. 2005. Women's and children's rights in a human rights based approach to development. New York: UNICEF.

Guba, Egon, \& Yvonna Lincoln. 1989. Fourth Generation Evaluation. Newbury Park: Sage Publications.

Guest, Greg, Emily E. Namey and Marilyn L. Mitchell. 2013. "Participant Observation.” Pp. 75-112 in Collecting Qualitative Data: A Field Manual for Applied Research, edited by G. Guest, E. E. Namey and M. L. Mitchell. Retrieved January 22, 2019 (https://www.sagepub.com/sites/default/files/upm-binaries/48454_ch_3.pdf).

Hamzaj, Enkelejda. 2015. "Jurgen Habermas and the critical theory of the society." WEI International academic conference proceedings. Retrieved October 4, 2019 (http://westeastinstitute.com/wp-content/uploads/2015/04/Enkelejda-Hamzaj. pdf).

Kumar, Chinta. 2013. "The eclectic method-Theory and its application to the learning of English language." International Journal of Scientific and Research Publications 3 (6): 1-4.

Lamont, Corliss. 1997 [1949]. The Philosophy of Humanism. 8th Ed. Amherst, New York: Humanist Press.

Louai, Habib. 2012. "Retracing the concept of the subaltern from Gramsci to Spivak: Historical developments and new applications." African journal of history and culture 4(1): 4-8. DOI: 10.5897/AJHC11.020.

Mehta, Neeta. 2019. "Parentification: A Disguised Form of "Child Labour." in the Family System.” IOSR Journal of Humanities and Social Science (IOSR-JHSS) (8): 8-11.

Odrowaz-Coates, Anna. 2017. "Revisiting Power and Supremacy in the Post-Colonial World. Globalisation as a Refined Phase of Colonization." Pp. 13-23 in Symbolic Violence in Socio-Economic Contexts: A Post-colonial Critique, edited by A. 
Odrowaz-Coates and G. Sribas. Warsaw: Wydawnictwo Akademii Pedagogiki Specjalnej.

Okam, Chinyere Lilian. 2014. “Theatre for Development as Participatory Evaluation Methodology." in A study of the Millennium Village Project, Pampaida-Nigeria. An Unpublished Doctoral Dissertation. Ahmadu Bello University, Zaria-Nigeria.

Okam, Chinyere, Lilian. 2019. "A pedagogic complexus on the knowledge and impact of economic recession on secondary school students." International Journal of Pedagogy Innovation and New Technologies 6(1): 37-44.

Onuekwe, C. E and Okam Chinyere, Lilian 2017. "Gender Disparity and Psycho-sexual Violence: An X-ray of How Imbalance is perpetuated by Sexual Behavior.” Journal of Gender and Power. Faculty of Educational Studies 8(2): 35-54.

Ozumba, G. O. 2010. Philosophy of Integrative Humanism. Calabar, Nigeria: Joschrisam Publishers.

Ozumba, G.O. and Chimakonam J.O. 2014. Njikoka Amaka: Further Discussions on the Philosophy of Integrative Humanism. Logic Option Publishing, Calabar. Print.

Partnership Initiative in the Niger Delta (PIND) Briefing. 2017. "The Street Kids of Calabar: A Punitive Approach is Not Enough.” Retrieved January 22, 2019 (https://fundforpeace.org/wp-content/uploads/2018/08/PIND-Briefing-TheStreet-Kids-of-Calabar-February-2017.pdf).

Sen, Amartya. 1999. Development as freedom. Oxford: Oxford University Press.

Sen, Amartya. 2000. “Social Exclusion: Concept, Application, and Scrutiny.” Social Development Papers 1. Office of Environment and Social Development Asian Development.

Bank, June. 2000. Social Exclusion. Retrieved January 22, 2019 (https:/www.adb.org/ sites/default/files/ publication/29778/social-exclusion.pdf).

Shortall, Sally and Mark Shucksmith. 1998. "Integrated Rural Development: Issues arising." The Scottish Experience. European Planning Studies 6(1): 73-88.

Spivak, Gyatari. 1988. “Can the subaltern speak?” Pp. 271-313, in Marxism and the Interpretation of Culture, edited by C. Nelson and L. Grossberg. Urbana,Chicago: University of Ilinois Press.

Zakir, A., Abubakar, U., Lawal, U.S., Imrana, H., Habibu, I. T., Hassan, I. H., and Harande M. M. 2014. "The practice of Almajiri: Prospect and socio-medical Challenges in Northern Part of Nigeria." Journal of African Studies and Development 6(7): 128131. DOI:10.5897/JASD20014.0273. 


\section{BIOGRAPHICAL NOTE}

Chinyere L. Okam, PhD, Lecturer at Faculty of Arts, University of Calabar Calabar, Cross River, Nigeria. Interested in Development and Pedagogical Theatre especial in the use of diverse methodologies.

OPEN ACCESS: This article is distributed under the terms of the Creative Commons Attribution Non-commercial License (CC BY-NC 4.0) which permits any non-commercial use, and reproduction in any medium, provided the original author(s) and source are credited.

ARTICLE HISTORY: Received 2019-10-12 / Accepted 2019-12-11 
